Bangladesh J. Plant Taxon. 27(1): 129-136, 2020 (June)

(C) 2020 Bangladesh Association of Plant Taxonomists

\title{
MYCOFLORA ASSOCIATED WITH SYMPTOMATIC LEAVES OF RAUVOLFIA SERPENTINA (L.) BENTH. EX KURZ. IN BANGLADESH
}

\author{
Zuhra Yasmin AND Shamim Shamsi* \\ Department of Botany, University of Dhaka, Dhaka-1000, Bangladesh
}

Keywords: Mycoflora; Symptomatic leaves; Rauvolfia serpentina; Bangladesh.

\begin{abstract}
Fifteen fungal species representing 12 genera were found to be associated with leaf spot and anthracnose diseases of Rauvolfia serpentina (L.) Benth. ex Kurz. which were collected from different habitats of Bangladesh. Fungi were isolated following 'tissue planting' and 'blotter' method. The isolated fungi were Alternaria alternata (Fr.) Keissler, Aspergillus flavus Link ex Fr., A. niger van Tieghm, Colletotrichum gloeosporioides (Penz.) Sacc., Curvularia lunata (Wakker) Boedijn, Fusarium sp.1. Fusarium sp. 2, Macrophoma sp., Nigrospora sphaerica (Sacc.) Mason, Penicillium digitatum Saccardo, Penicillium italicum Whemer, Pestalotiopsis guepinii (Desm.) Stay, Pseudocercospora libenbergii (Syd.) Deighton, Rhizopus stolonifera Vuillemin. Toney, Trichoderma viride Pers. During the present investigation, Pseudocercospora libenbergii is a new record for Bangladesh.
\end{abstract}

\section{Introduction}

Rauvolfia serpentina is an evergreen shrub that is a member of the dogbane or Apocynaceae family. It is native to tropical and subtropical regions of the world, including Europe, Africa, Asia, Australia, and the Central and South Americas. It is naturally grows in the moist, deciduous forests of southeast Asia, including India, Burma, Bangladesh, Sri Lanka, and Malaysia. All parts of the plant, including the stem and leaves, contain indole alkaloids, but they are found in highest concentration in the bark of the root (Ahmed et al., 2008). The identified indole and indole alkaloids include ajmalidine, ajmaline, ajmalinine, ajmalicine, aricine, canescine, coryanthine, deserpidine, isoajmaline, isoserine, isoserpiline, lankanescine, neoajmaline, papaverine, raubasine, raucaffricine, rauhimbine, rauwolfinine, recanescine, rescinnamine, reserpiline, reserpine, reserpinine, sarpagine, serpentine, serpentinine, thebaine, yohimbine, and yohimbinine. Reserpine is a potent alkaloid first isolated from this plant which is being widely used as an antidote for high blood pressure and an anti hypersensitive drug (Yusuf et al., 2009). The root extract of this plant is very useful in disorder of gastrointestinal tract viz., diarrhea, dysentery and cholera and coli. Reserpine is distributed throughout the body to the brain. liver, spleen, kidney, and adipose tissue. It has been studied for the treatment of mental diseases, including schizophrenia and bipolar disorder, epilepsy and seizures, and of insomnia, sleep problems and anxiety (Kapoor 1990 and Lobay, 2015). Aqueous extract of whole plant, stem and roots of $R$. serpentina were evaluated for antifungal activity. The aqueous root extract of the plant showed significant higher antifungal activity against Alternaria alternata and Aspergillus flavus than the other extracts under study (Thakur et al., 2015). International Union for Conservation of Nature (IUCN) has placed this plant under endangered status (Mabberley, 2008). The roots of $R$. serpentina contain numerous alkaloids. Its indiscriminate use and poor method of conventional propagation have led this

*Corresponding author, e-mail: prof.shamsi@gmail.com 
species to be included in the list of endangered plants. Most of the research work carried out on it falls under Phytochemical, Pharmacological, Biochemical and Antimicrobial disciplines (Ghani, 2003; Panda, 2004; Bunkar, 2017). But research about its fungal diseases is inadequate (Yasmin and Shamsi 2015).

Aanthracnose and leaf spots are two common diseases of $R$. serpentina in Bangladesh. Chandra (1957) was reported the leaf blotch disease of $R$. serpentina including anthracnose and leaf spot, Mukerji and Bhasin (1986) was also reported target leaf blotch, Cercospora leaf spot, die-back, powdery mildew and Fusarium wilt, and root-knot diseases of $R$. serpentina from India. The main purpose of the present study was conducted to find out the existence and identification of mycoflora living on infected $R$. serpentina phylloplane.

\section{Materials and Methods}

For the present investigation sampling area were field plots of Botanical garden, Curzon Hall Campus, Dhaka University; Lawachara, Sylhet; Botanic garden, Chittagong University campus and Mymensingh of Bangladesh. Two types of symptoms viz., anthracnose and leaf spot were recorded from leaves of $R$. serpentina during the tenure of 2007 to 2013. Infected leaf samples were placed in clean brown paper bag, labeled properly and preserved at $4^{\circ} \mathrm{C}$ in refrigerator for future studies.

The fungi associated with the collected samples were isolated following 'Tissue planting' method on PDA (Potato Dextrose Agar) medium and 'Blotter method'. Isolation procedure was followed by (Yasmin and Shamsi, 2015).

Detailed morphological studies of the fungal isolates were made in order to determine their identification. The microscopic structural characters of the isolated fungi were recorded under Nikon D 5000 digital camera. Then isolates fungi were identified based on following standard literatures (Barnett and Hunter, 1972; Booth 1971; Ellis 1971, 1976; Ellis and Ellis 1997; Thom and Raper 1945; Raper et al. 1949 and Sutton 1980). The experiment was conducted in the Laboratory of Mycology and Plant Pathology, Department of Botany, University of Dhaka and all the specimens were preserved in this laboratory.

\section{Results and Discussion}

Fifteen fungal species representing 12 genera were found to be associated with leaf spot and anthracnose diseases of $R$. serpentina namely, Alternaria alternata (Fr.), Aspergillus flavus, A. niger, Colletotrichum gloeosporioides, Curvularia lunata , Fusarium sp.1, Fusarium sp.2, Macrophoma sp., Nigrospora sphaerica, Penicillium digitatum, P. italicum, Pestalotiopsis guepinii, Pseudocercospora libenbergii, Rhizopus stolonifera and Trichoderma viride. Of these, Pseudocercospora libenbergii is a new record for Bangladesh.

\section{Taxonomic treatment of fungal taxa}

1. Alternaria alternata (Fr.) Keissler 1912. Beih. Bot. Zbl. 29: 433

(Fig. 1A)

Colony usually black or olivaceous black, sometimes grey. Conidiophores golden brown, smooth, up to $50 \times 3-6 \mu \mathrm{m}$. Conidia formed in long, often branched chains, obclavate, obpyriform, ovoid or ellipsoidal, often with a short conidial or cylindrical beak, pale to mid golden brown, smooth or verruculose, with up to 8 transverse and usually several longitudinal or oblique septa, 29.6-65.6 (75.6) $\mu \mathrm{m}, 6-20.4 \mu \mathrm{m}$ thick in the broadest part; beak pale, 2.4-5 $\mu \mathrm{m}$ thick.

Specimen examined: Isolates from leaf spot symptom of Rauvolfia serpentina, dist.- Dhaka, ZY, 18, 23 April 2007. 
2. Aspergillus flavus Link 1809. Magazin der Gesellschaft Naturforschenden Freunde Berlin 3(1): 16

(Fig. 1B)

Colonies effuse greenish. Mycelia well developed, septate, hyaline and profusely branched. Conidiophores 300-600 $\mu \mathrm{m}$. Conidia greenish, catenulate, globose or pyriform, smooth, $3-5 \mu \mathrm{m}$ in diameter.

Specimen examined: Isolates from anthracnose symptom of $R$. serpentina, dist - Dhaka, ZY 141, 3 August 2008.

3. Aspergillus niger van Tieghem 1867. Ann. Sci. Nat. Bot. Ser. 5, 8: 240.

(Fig. 1C)

Colonies effuse, black. Conidiophores brown $200-400 \times 7-10 \mu \mathrm{m}$. Vesicles globose or sub globose, thick walled, commonly $20-50 \mu \mathrm{m}$, occasionally up to $100 \mu \mathrm{m}$ in diameter. Foot cell present. Sterigmata $20-30 \times 6-8 \mu \mathrm{m}$. Conidia dark brown, one celled, globose, $2-4$ (5) $\mu \mathrm{m}$ in diameter.

Specimen examined: Isolates from anthracnose symptom of $R$. serpentina, dist - Dhaka, ZY 21, 23 April 2007.

4. Colletotrichum gloeosporioides (Penz.) Sacc., Fung. Agrum. 2:6 (1882)

(Fig. 1D)

Colony cottony, white, grayish, reverse grayish black at maturity. Setae absent. The waxy acervuli, that are produced in infected tissue, are subepidermal, typically with setae, and simple, short, erect conidiophores. Masses of conidia appear pink or salmon colored. The fungus produces hyaline, one- celled, ovoid to oblong conidia, comparatively large, straight, obtuse at the apex, 14.8-24.4 $\times 3.6-5.2 \mu \mathrm{m}$. Appressoria abundant, pale to medium brown, circular or slightly irregular.

Specimen examined: Isolates from anthracnose symptom of $R$. serpentina, dist- Dhaka, ZY 51, 15 July 2007.

5. Curvularia lunata (Wakker) Boedijn 1933. Bull. Jard. Bot. Buitenz. 13(1): 123

(Fig. 1E)

Colonies effuse grayish black, hairy, cottony or velvety. Conidiophores solitary, unbranched, straight or slightly undulating, geniculate, mid brown, septate, 37- $64 \times 9.2-14.4 \mu \mathrm{m}$. Conidia dark brown, mostly 3 -septate, mostly curved, third cell from the base is broader and darker then others, broader cells mid brown, other cells paler, smooth, $22.5-31.2 \times 9.3-12.6 \mu \mathrm{m}$.

Specimen examined: Isolates from anthracnose symptom of $R$. serpentina, dist -Dhaka, ZY 127, 16 April 2008.

6. Fusarium sp. 1 Sheldon 1904. Rep. Neb. Agric. Exp. Stn 17: 23-32

(Fig. 1F) Mycelium extensive and cottony, white, often with some tinge of pink. Reverse pinkish yellow. Mycelia hyaline, profusely branched, septate. Conidiophores hyaline 0-2 septate. Phialides hyaline, $16-20 \times 3-4 \mu \mathrm{m}$. Conidia hyaline, variable, Microconidia 1-celled, ovoid or oblong, borne singly or in chains, $5-15 \times 2-3 \mu \mathrm{m}$.

Specimen examined: Isolates from leaf spot symptom of $R$. serpentina, dist -Dhaka, ZY 15 , 27 March 2007.

7. Fusarium sp. 2 Sheldon 1904. Rep. Neb. Agric. Exp. Stn 17: 23-32

(Fig. 1G)

Mycelium extensive and cottony, white. Reverse pinkish yellow. Mycelia hyaline, profusely branched, septate. Conidiophores hyaline 0-2 septate. Phialides hyaline, 3.6 - $10 \times 3-4 \mu \mathrm{m}$. Conidia hyaline, variable. Microconidia 1-celled, ovoid or oblong, borne singly or in chains, 5 - 10 $\times 2-3 \mu \mathrm{m}$. 
Specimen examined: Isolates from leaf spot symptom of $R$. serpentina, dist -Dhaka, ZY 68, 5 August 2007.
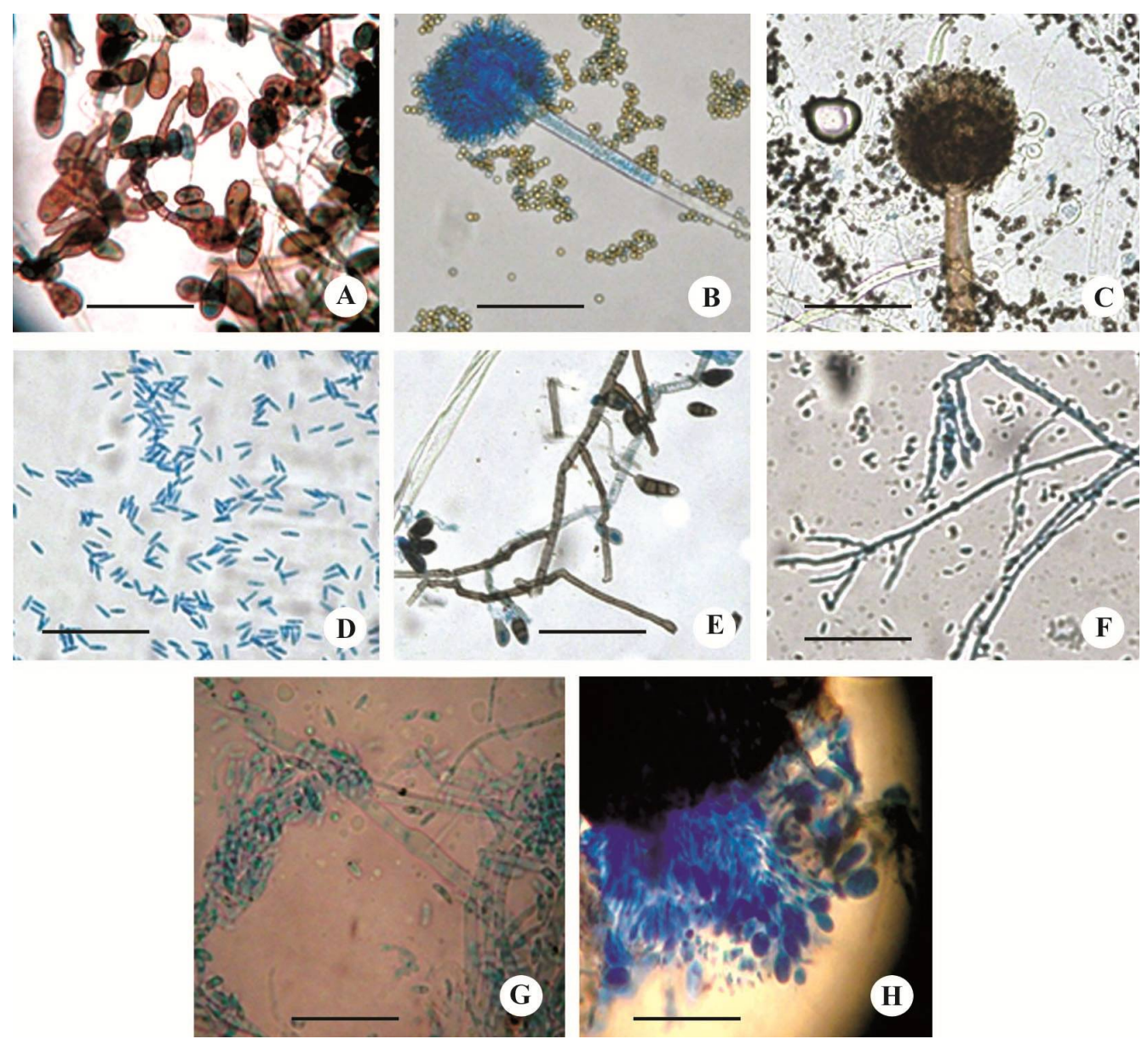

Fig 1. Conidiophores and conidia of A. Alternaria alternata, B. Aspergillus flavus, C. A. niger and D. Colletotrichum gloeosporioides, E. Curvularia lunata, F. Fusarium sp.1, G. Fusarium sp. 2 and H. Pycnidia of Macrophoma sp. $($ Bar $=50 \mu \mathrm{m})$.

8. Macrophoma sp. Berl. and Vogl.

(Fig. 1H)

Pycnidia dark, ostiolate, globose, erumpent ; Conidiophores simple, short or elongate ; Conidia hyaline, 1-celled, over 15 microns long, ovoid to broadly ellipsoid ; parasitic.

Specimen examined: Isolates from anthracnose symptom of $R$. serpentina, dist -Dhaka, ZY 10, 27 March 2007.

9. Nigrospora sphaerica (Sacc.) Manson, 1927, Trans.Br.mycol Soc, 12:158

(Fig. 2A)

Conidiophores 4-8 $\mu \mathrm{m}$ thick. Coridiogenous cells 8-11 $\mu \mathrm{m}$ diam. Conidia 14-20 (mostly 16-

18) $\mu \mathrm{m}$ diam. 
Specimen examined: Isolates from anthracnose symptom of $R$. serpentina, dist-Chittagong, ZY 146, 3 August 2009.

10. Penicillium digitatum (Fr.) Sacc. 1910. Bur. Anim. Ind., Bul. 118: 31-33

(Fig. 2B)

Colony small, cottony, greenish, reverse creamy. Hyphae creeping, septate, branched, hyaline. Conidiophores erect, apically irregularly verticillate-penicillately branched, $15-28 \times 3.5-5.0 \mu \mathrm{m}$. Conidia catenulate, spherical or elliptical, smooth, white in mass, commonly $3.5-5.0 \mu \mathrm{m}$.

Specimen examined: Isolates from leaf spot symptom of $R$. serpentina, dist-Chittagong, ZY 147, 3 August 2009.

11. Penicillium italicum Wehmer, Hedwigia 33 : 211- 214. 1894

(Fig. 2C)

Colonies on PDA medium growing restrictedly, often marked by a few shallow furrows, with margins usually its inner surface pale gray- green shades. Penicilli asymmetric, often comparatively long up to $50-70 \mu \mathrm{m}$ and $3-5 \mu \mathrm{m}$ width, bearing tangled chains of conidia. Strigmata 3-6 in a whole 8-10 $\times 3.5 \mu \mathrm{m}$. Conidia one celled with greenish tinge, $4-5 \times 25-35 \mu \mathrm{m}$.

Specimen examined: Isolates from leaf spot symptom of $R$. serpentina, dist - Mymensingh, ZY 135, 24 April 2008.

12. Pseudocercospora liebenbergii Sydow. Ann. Mycol. 33: 235. 1935

(Fig. 2E-F)

Leaf spots subcircular to irregular, single or confluent, 5- $10 \mathrm{~mm}$, in diameter, at first uniformly red to reddish brown, after which the center gradually becomes dingy gray, fruiting amphigenous but more abundant on the upper leaf surface, stromata dark brown, globular to elongate, $30-50 \mu \mathrm{m}$, fascicles dense to very dense, conidiophores in mass dark brown singly pale to very pale olivaceous brown, paler and more narrow toward the tip which occasionally is bifurcate, seldom septate, 0-1 geniculate, small spore scar at the narrowly rounded tip, 3-5 × 5-35 $\mu \mathrm{m}$, base sometimes wider; conidia subhyaline to pale olivaceous, cylindro - obclavate, shortest ones may be distinctly cylindric, straight to curved, indistinctly multiseptated, base long obconically truncate, tip obtuse to conically acute, $2.5-4 \times 25-70 \mu \mathrm{m}$.

Specimen examined: I Isolates from leaf spot symptom of $R$. serpentina, dist - Dhaka, ZY 125, 15 March 2008.

13. Pestalotiopsis guepinii (Desm.) Stay. Bulletin du Jardin Botanique de IEtat a Bruxelles 19(3): 312

(Fig. 2D)

Colonies white, cottony. Mycelia hyaline, septate, profusely branched, fruiting structure black, shining, conspicuous, condiomata $200 \mu \mathrm{m}$. Conidiophores short, hyaline, $10-15 \times 1-2$ $\mu \mathrm{m}$, mostly aseptate with 1-2 proliferation. Conidia blackish brown, mostly three septate with $2-5$ hyaline appendages at the apex and short hyaline appendage at the base, apical appendages $16-33$ $\mu \mathrm{m}$ long and basal appendage $4-12 \mu \mathrm{m}$ long.

Specimen examined: Isolates from leaf spot symptom of $R$. serpentina, dist-Chittagong, ZY 79, 20 August 2007.

14. Rhizopus stolonifera (Ehrenb.: Fr.) Vuillemin 1902. Toney Bot. Clup. 69: 592 - 616.

(Fig.2G)

Colonies grayish, fluffy. Reverse light gray. Mycelium coenocytic, well developed, branched and fluffy. Mycelium produces long conidiophores, 300-700 $\mu \mathrm{m}$ long and 3-4 $\mu \mathrm{m}$ in width, many aerial stolons also develop rhizoids at certain points. Directly above the rhizoids one or more sporangiospores are produced. The top of each sporangiophores becomes swollen as the latter 
reaches maturity and a sporangium is developed. Columella present. Sporangium produces non motile, brownish sporangiospores, $4-6 \mu \mathrm{m}$ in diameter.

Specimen examined: Isolates from leaf spot symptom of $R$. serpentina, dist-Sylhet, ZY 55, 15 July 2007.
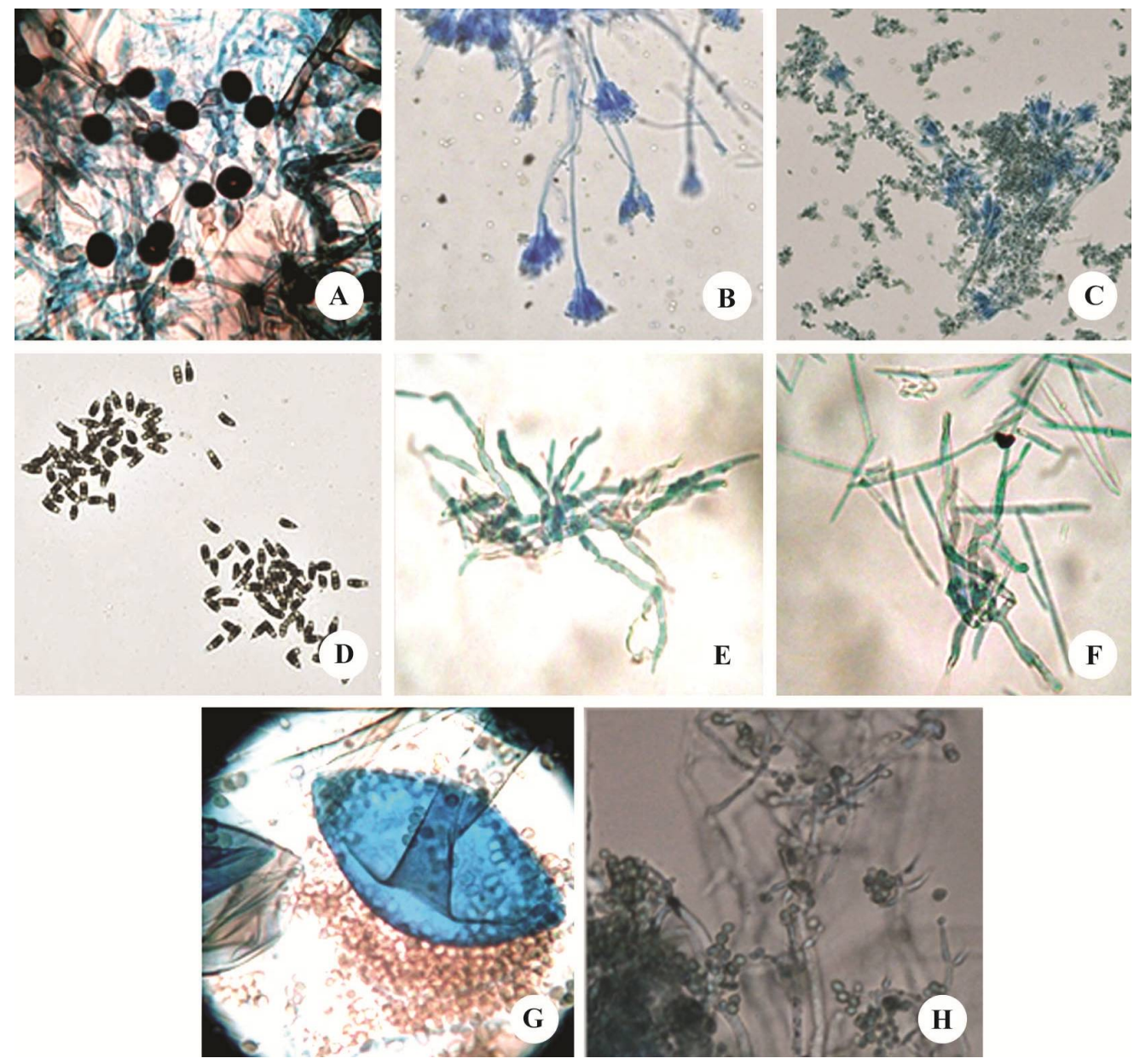

Fig 2. Conidiophores and conidia of A. Nigrospora sphaerica. B. Penicillium digitatum, C. Penicillium italicum and D. Acervuli, conidiophores and conidia of Pestalotiopsis guepinii, E-F. Pseudocercospora liebenbergii, G. Rhizopus stolonifer and $\mathrm{H}$. Trichoderma viride $(\mathrm{Bar}=50 \mu \mathrm{m})$.

15. Trichoderma viride Pers. 1794. Neues Magazin fur die Botanik 1: 92

(Fig. 2H)

Colony effuse, light green, hyphae elongate. Conidiophores hyaline, upright, much branched, bearing phialides single or in groups. Conidia hyaline, powdery mass, globose, 1-celled, ovoid, borne in small terminal clusters $3.5-5 \mu \mathrm{m}$, usually easily recognized by its rapid growth and green patches or cushions of conidia.

Specimen examined: Isolates from anthracnose symptom of $R$. serpentina, dist Mymensingh, ZY 78, 20 August 2007. 
A detailed survey of literature revealed that Pseudocercospora libenbergii has not been reported in any relevant literature of Bangladesh (Talukar 1974, Siddiqui et al., 2007; Shamsi 2017 and 2018). Hence, Pseudocercospora libenbergii Deighton reported here as a new fungal record for Bangladesh.

\section{Acknowledgement}

The first author (ZY) gratefully acknowledges the financial support by the Ministry of Science and Technology, Government of the People's Republic of Bangladesh through NSICT fellowship.

\section{References}

Ahmed, Z.U., Begum, Z.N.T., Hassan, M.A and Khondker, M., Kabir, S.M.H., Ahmed. M., Ahmed, A.T. A., Rahman, A.K.A and Haque, E.U. (Eds.) 2008. Encyclopedia of Flora and Fauna of Bangladesh, Vol. 6. Angiosperms: Dicotyledones (Acanthaceae-Asteraceae) Asiatic society of Bangladesh, Dhaka. pp. 408.

Barnett, H.L. and Hunter, B.B. 1972. Illustrated genera of imperfect fungi. 4th edition.Pub. Co. The American Phytopathological Society, St. Paul, Minnesota. pp.185.

Booth, C. 1971. The Genus Fusarium. The Commonwealth Mycological Institute, Kew, Surry, England. pp. 273.

Bunkar, A. R. 2017. Therapeutic uses of Rauwolfia serpentina. International Journal of Advanced Science and Research. 2(2): 23-26.

Chandra, V. 1957. Leaf blotch disease of Rauvolfia serpentina. Sci. Cult., 23: 99-99.

Ellis, M.B. 1971. Dematiaceous Hyphomycetes. The Commonwealth Mycological Institute, England. pp 608.

Ellis, M.B. 1976. More Dematiaceous Hyphomycetes. The Commonwealth Mycological Institute, England. pp.608.

Ellis, M.B. and Ellis, J.P. 1997. Micro Fungi on Landplants. An Identification Handbook. The Commonwealth Mycological Institute, England. pp. 868.

Ghani, A. 2003. Medicinal plants of Bangladesh. Asiatic Society of Bangladesh. pp.603.

Kapoor, L.D. 1990. CRC Handbook of Ayurvedic Medicinal plants.CRC Press, Inc. Boca Raton Florida pp.416.

Lobay, D. 2015. Rauwolfia in the Treatment of Hypertension. Integr Med (Encinitas). 14(3): 40-46.

Mukerji, K.G. and Bhasin, J. 1986. Plant diseases of India. A source Book. Tatta Mc.Grew-Hill Publishing Company Ltd. New Delhi, pp. 467.

Panda, H. 2004, Medicinal Plants Cultivation and their Uses, Delhi, Asia Pacific Business Press, pp. 550.

Mabberley, D.J. 2008. Mabbeevly's plant- Book, A portable dictionary of plants their clarification and uses, $3^{\text {rd }}$ edn. Cambridge University press, Cambridge.xviii+1021.

Raper, K. B. and Thom, C. and. Fennel. L.1949. A Manual of the Penicillium. The Willium and Wilkins. Company, Baltimore, U. S. A. pp.875.

Shamsi, S. 2017. Checklist of deuteromycetous fungi of Bangladesh I. J. Bangladesh Acad. Sci. 41(2): 115-126.

Shamsi, S. 2018. Morphological and molecular detection of fungi in Bangladesh. Trends in biochemistry and molecular biology. Nova Science Publishers. New York. pp. 419.

Siddiqui, K.U., Islam, M.A., Begum, Z.N.T., Hassan, M.A., Khandker, M., Rahman, M.M., Kabir, S.M.H., Ahmad, M., Ahmed, A.T.A., Rahman, A.K.A. and Haque, E.U. (eds.), 2007. Encyclopedia of flora and faana of Bangladesh. Vol.2. Cyanobacteria, Bacteria and Fungi. Asiatic Society of Bangladesh, Dhaka. $415 \mathrm{pp}$

Sutton, B.C. 1980. The Coelomycetes. Fungi Imperfecti with Pycnidia, Acervuli and Stromata. Commonwealth Mycological Institute, Kew, Surrey, England. pp 696.

Talukdar, M.J. 1974. Plant diseases in Bangladesh. Bangladesh J. Agric. Res. 1(1):61-86. 
Thakur, N., Jagota, K., Shama, B. and Sareen, N. 2015. Evaluation of in vitro antifungal potential of Rauvolfia (L.) Benth. ex Kurz. Against phytopathogenic fungi. I.J.S.N., 6(2): 165-168.

Thom, C. and Raper, K.B. 1945. A Manual of the Aspergilli. The Williams \& Wilkins Company. Baltimore. pp. 373.

Yusuf, M. Begum, J. and Chowdhury, J.U. 2009. Medicinal plants of Bangladesh. BCSIR Laboratories, Chittagong. pp. i-x+ 794.

Yasmin, Z. and S. Shamsi.2015. Report on anthracnose of Rouwolfia serpentina (L.) Benth ex Kurz caused by Colletotrichum gloeosporioides (Penz.) Sacc. from Bangladesh. J. Asiat. Soc. Bangladesh. Sci. 41(2): 183-192.

(Manuscript received on 06 June 2019; revised on 12 June 2020) 